\title{
Prednosti i nedostatci kohortnih i case-control studija
}

\section{Advantages and disadvantages of cohort and case-control studies}

\author{
Vanja Giljača*, Davor Štimac
}

Zavod za gastroenterologiju, Klinika za internu medicinu, Klinički bolnički centar Rijeka, Rijeka

\section{"Dopisni autor:}

dr. sc. Vanja Giljača, dr. med. Zavod za gastroenterologiju, Klinika za internu medicinu Klinički bolnički centar Rijeka Krešimirova 42, 51000 Rijeka e-mail: vanja.giljaca@gmail.com
Sažetak. Liječnici vrlo često svojim pacijentima trebaju dati savjet o promjeni stila života, kako bi se na najmanju moguću mjeru svela vjerojatnost od oboljenja od neke bolesti. Također, potrebno je odabrati i ispravan lijek za liječenje određenih bolesti. Podatke koji im mogu olakšati ove odluke moguće je pronaći i u kohortnim i case-control studijama. Ove studije su relativno jeftine, jednostavne za provođenje, a rezultati su dostupni u relativno kratkom vremenu. No, potrebno je biti svjestan prednosti i nedostataka ovakvih studija kako bi se rezultati mogli interpretirati sa sigurnošću i kako bi se mogle donositi ispravne kliničke odluke.

Ključne riječi: bias; case-control studije; confounding; kohortne studije; opservacijske studije

Abstract. Physicians are very often invited by their patients to give lifestyle advice to reduce the odds of contracting a certain disease. Also, it is necessary for physicians to choose adequately among different therapeutic modalities for any disease. The data that may make these choices easier come from cohort and case-control studies. These studies are of relatively low cost and simple to undertake and the results are available in a relatively short time. However, one must be aware of advantages and disadvantages of these types of studies so that the results can be interpreted with certainty in order to make correct clinical decisions.

Key words: bias; case-control studies; cohort studies; confounding; observational studies

http://hrcak.srce.hr/medicina 


\section{UVOD}

U kliničkoj praksi liječnici se vrlo često susreću s mnogobrojnim odlukama o tome kako dijagnosticirati bolesti i optimalno liječiti svoje pacijente. U procesu odlučivanja koju metodu dijagnostike ili liječenja primijeniti, uvijek se vode dokazima koji su na raspolaganju u medicinskoj literaturi. Dokazi u medicini dolaze iz različitih izvora, a najčešći su oni iz znanstvenih istraživanja. Stoga bi se, kod izbora liječenja svojih pacijenata, liječnici morali moći osloniti na dokaze koje mogu pronaći u rezultatima različitih znanstvenih i kliničkih istraživanja. No sva istraživanja nisu jednako vrijedna, odnosno rezultati svih vrsta kliničkih istraživanja ne mogu se uvijek razmatrati kao nešto što je apsolutna istina. Naravno, postoje istraživanja kojima možemo vjerovati više, ali postoje i ona istraživanja čiji rezultati na prvi pogled izgledaju vrlo vjerodostojni, no nakon pomnije analize i čitanja rezultata takvih istraživanja nailazimo na moguće probleme $u$ interpretaciji te različite vrste skretanja rezultata (engl. bias) ili neočekivanih utjecaja na rezultate (engl. confounding). Sva istraživanja moramo uvijek gledati kroz kritičku prizmu i pokušati objektivno procijeniti koliko su rezultati vjerodostojni. Naime, svako istraživanje u svojim metodama i rezultatima može skrivati različite izvore skretanja rezultata. Ovakva skretanja, odnosno bias i confounding, nisu posljedica loše kvalitete znanstvenog rada ili pomanjkanja znanja ili etičnosti istraživača - to su urođeni nedostatci svake znanstvene studije. Ovu činjenicu moramo uvijek imati na umu kada čitamo neki znanstveni rad, a posebno kada rezultate znanstvenih radova primjenjujemo kao dokaze kojima potkrjepljujemo svoje odluke u svakodnevnom radu i liječenju svojih pacijenata. Dakle, koja su to istraživanja koja nas svojim rezultatima mogu navesti na pogrešne zaključke? Naravno, prema uvriježenom mišljenju, randomizirane kontrolirane studije (engl. randomised controlled trials RCT) najbolji su izvor dokaza. Medicina temeljena na dokazima danas se također oslanja na rezultate sustavnih pregleda i metaanaliza. Ovo su najbolji dokazi u medicini, no velika količina podataka i informacija o bolestima i njihovom liječenju dolazi iz tzv. opservacijskih studija.

\section{ŠTO SU OPSERVACIJSKE STUDIJE?}

Sva istraživanja u medicini možemo grubo podijeliti u dvije velike skupine. To su opservacijske studije i intervencijske studije. Opservacijske studije još nazivamo i 'prirodni eksperimenti' zato što u ovakvim studijama istraživači uzimaju grupe pacijenata s istim bolestima te ih prate tijekom određenog vremena kako bi vidjeli imaju li pojedine karakteristike pacijenata utjecaj na tijek bolesti. Također, pacijente se može pratiti i retrogradno, odnosno,

Opservacijske studije mogu biti vrlo korisne kliničarima u donošenju odluka. Ako se njihovi rezultati uzimaju bezrezervno, opservacijske studije mogu dovesti do značajnih pogrešaka u shvaćanju, a onda i u liječenju pacijenata.

opservacijska studija može se bazirati na već učinjenim intervencijama te se unatrag mogu analizirati učinci liječenja. Na primjer, mogu se opservirati dvije skupine pacijenata $s$ istom bolešću, koje su dobivale dva različita lijeka, te se na osnovu retrogradnih podataka može zaključivati koji bi lijek mogao biti bolji. Dakle, opservacijske studije mogu biti prospektivne ili retrospektivne ${ }^{1,2}$.

Nadalje, opservacijske studije mogu se podijeliti u deskriptivne i analitičke. Deskriptivne opservacijske studije jednostavno opisuju zapažanja tijekom procesa liječenja ili dijagnostike kod individualnih slučajeva ili grupa pacijenata. Ova grupa studija uključuje prikaz slučaja (engl. case report), seriju slučajeva (engl. case series) i presječne studije (engl. cross-sectional study). Prikaz slučaja navodi karakteristike jednog slučaja u kliničkoj praksi koji je po nekom kriteriju interesantan za liječnike, bilo da je to slučaj novog načina liječenja ili slučaj vrlo rijetke bolesti ili poveznice dvaju ili više simptoma u jednu cjelinu na novi način. Ovakvu studiju obično objavljuje jedan kliničar ili grupa liječnika koji su sudjelovali u liječenju jednog pacijenta. Serija slučajeva omogućuje pregled nekoliko pacijenata $\mathrm{s}$ istim karakteristikama bolesti te opisno donosi neka zapažanja kliničara koji su ove pacijente liječili. Presječne studije donose određena zapažanja kliničara u jednom trenutku u vremenu. Ove studije u pravilu nemaju statističkih metoda obrade podataka, ili su te metode svedene na opisne 

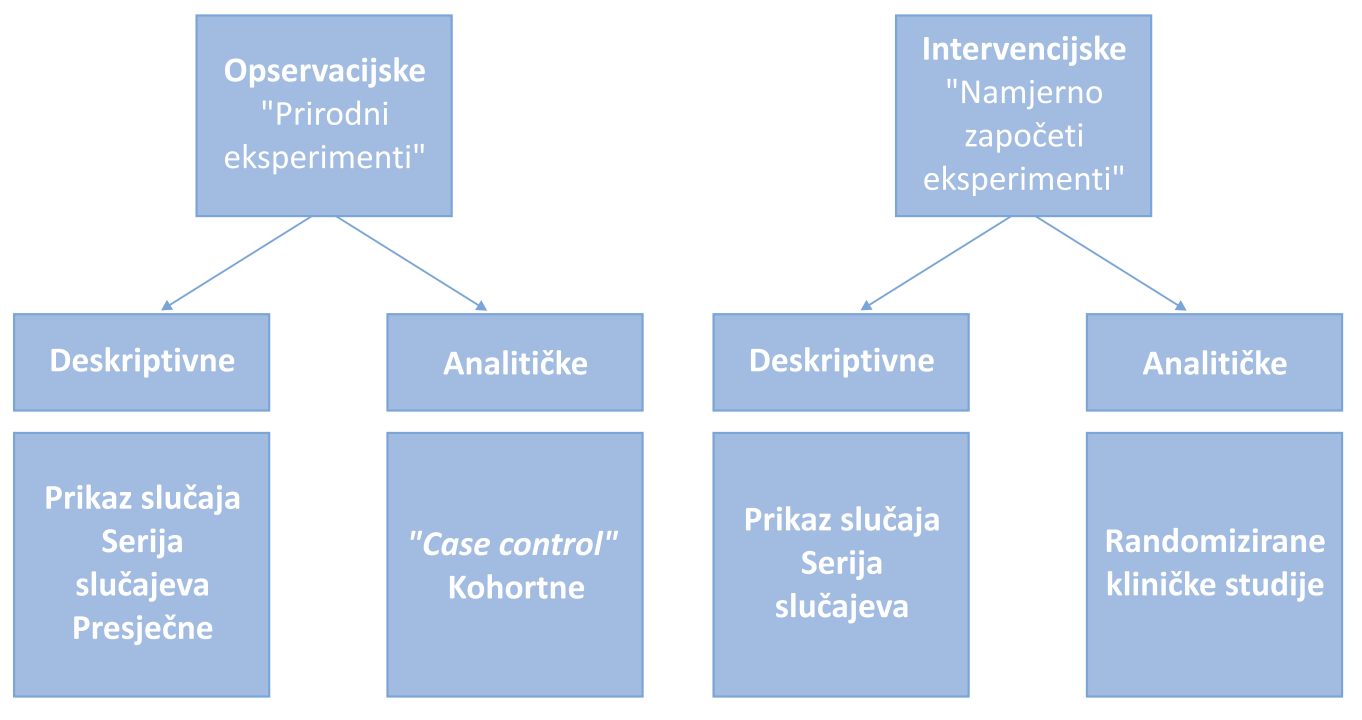

Slika 1. Vrste istraživanja u medicini

statističke rezultate kao što su srednje vrijednosti ili apsolutne količine i brojnost određenih frekvencija koje se opserviraju.

Analitičke opservacijske studije pokušavaju klinička zapažanja odvesti korak dalje, te svoja zapažanja i rezultate temelje na statističkoj obradi opserviranih frekvencija. Dakle, ove studije, osim što samo donose određene frekvencije pojavnosti, pokušavaju ih i objasniti tako da statistički traže poveznice između uzroka i posljedica u opserviranoj skupini pacijenata. $U$ analitičke opservacijske studije spadaju kohortne i case-control studije.

Vrste studija u biomedicinskim istraživanjima prikazane su na slici 1.

\section{KOHORTNE STUDIJE}

Kohortne studije su vrsta medicinskog istraživanja koja se koristi kako bi se istražili uzroci bolesti tako da se uspostavljaju poveznice između čimbenika rizika i zdravstvenih ishoda ${ }^{3}$. Ove studije omogućuju neke prednosti tako što mjere pojavnost bolesti i povezuju bolest i izloženost nekom faktoru rizika u kontekstu vremenske dimenzije, bilo kroz prospektivni ili retrospektivni pristup ${ }^{4,5}$. U retrospektivnom dizajnu kohortne studije prati se grupa ispitanika, tzv. kohorta, koja je bila izložena istom faktoru u prošlosti. Takva kohorta se zatim povezuje $s$ ishodima svakog pojedinačnog ispitanika u nekom kasnijem vremenu te se mjere frekvencije ili zastupljenost bolesti u takvih ispita- nika. Na primjer, možemo uzeti grupu pušača koji su godinama bili izloženi cigaretnom dimu te desetak godina kasnije mjeriti zastupljenost karcinoma pluća u ovakvoj skupini ispitanika.

Prospektivne kohortne studije imaju sličan, ali vremenski drugačiji dizajn. Naime, ove studije također uzimaju kohortu ispitanika, ali za razliku od retrospektivnih, prospektivne kohortne studije prate kohortu u vremenu, te na kraju nekog vremenskog roka istražuju pojavnost određene karakteristike koja je od interesa. Dakle, koristeći istu analogiju, prospektivna kohortna studija okupila bi određeni broj ispitanika koji su pušači te bi ih se pratilo određeni broj godina i na kraju tog vremenskog roka mogla bi se izmjeriti pojavnost karcinoma pluća u ovoj skupini ${ }^{6}$.

Prednosti retrospektivnih kohortnih studija su što su vrlo jeftine i jednostavne za organizirati. Naime, potrebno je prikupiti povijesne podatke o ispitanicima, što je dovoljno za analizu i dobivanje rezultata. Nadalje, smatra se da ovakve studije imaju prednost $u$ tome što istraživači nemaju utjecaj na odabir ispitanika, odnosno razina skretanja rezultata zbog subjektivnog odabira ispitanika je malena (engl. selectionbias). Budući da su vrlo jednostavne za izvođenje, retrospektivne kohortne studije mogu istovremeno pratiti velik broj ishoda za istu kohortu ispitanika. Rezultati ovakvih studija dostupni su u vrlo kratkom roku, jer je potrebno samo ekstrahirati već postojeće 
podatke iz dokumentacije o ispitanicima i učiniti analizu. Međutim, ovakve studije pate od nekoliko vrlo važnih nedostataka. Budući da su podaci već zabilježeni, istraživač ne može utjecati na kvalitetu, niti kvantitetu podataka koje prikuplja i analizira. Drugi vrlo važan nedostatak je to što se podaci temelje na sjećanju ispitanika o tome kada i kako su bili izloženi rizičnom faktoru (engl. recallbias). Naime, ispitanici koji imaju neki ishod višestruko su skloniji taj ishod povezati s izloženošću nekom faktoru od ispitanika koji ishod nemaju. Primjerice, ispitanici koji, nažalost, boluju od karcinoma pluća, sigurno svoju bolest povezuju s pušenjem. No, oni ispitanici koji su također pušači, ali nemaju karcinom pluća, sigurno u pušenju neće s tolikom vjerojatnošću pronaći velik problem, odnosno neće ga smatrati velikim rizikom. Još jedan važan nedostatak retrospektivnih studija je tzv. modifikacija efekta, što znači da utjecaj izloženosti nekom faktoru ovisi o nekoj drugoj varijabli koja možda nije mjerena kod uzimanja podataka. Na primjer, pušači koji boluju od karcinoma pluća možda su u većem postotku, zbog svog posla ili zbog uvjeta života, bili izloženi azbestu od onih koji nemaju karcinom,. Ovakva paralelna izloženost vrlo se često zaboravlja istaknuti u podacima na kojima se baziraju rezultati kohortnih studija, a vrlo su važni, jer mogu značajno utjecati na ishod i rezultate ovakvih studija.

Prospektivne kohortne studije imaju prednost što su u mogućnosti uspostaviti vremensku vezu između izloženosti i ishoda. Budući da se ispitanici prate prospektivno, može se za svakog pojedinog ispitanika utvrditi kada je nastala bolest te se bolest, odnosno ishod, može povezati s izloženošću nekom faktoru tijekom istraživanja. Ovakav dizajn studije vrlo je povoljan za praćenje rijetkih ishoda, odnosno rijetkih posljedica neke vrste izloženosti, zato jer se određena skupina ispitanika može dugotrajno pratiti. Treća prednost prospektivnih kohortnih studija je u tome što ispitivač ima mogućnost određivanja kriterija ispitivanja. Kako se radi o prospektivnim studijama, ispitivač kod dizajniranja studije može unaprijed odrediti koje karakteristike će istraživati kod ispitanika te onda uključivati u studiju samo ispitanike s ovim, unaprijed definiranim karakteristikama.

Nedostatci prospektivnih kohortnih studija su u tome što je vrlo teško zadržati ispitanike koji nisu izloženi nekom faktoru. Obično se interes ispitanika smanji tijekom vremena, a pogotovo je to slučaj s ispitanicima koji nemaju rizični faktor koji se istražuje. Takvi ispitanici često se izgube iz istraživanja, a s njima i njihovi prospektivni podaci. Ovakva istraživanja relativno su skupa, budući da uključuju bilježenje prospektivnih parametara ispitanika, a to znači da je potrebno ispitanike redovito pratiti i pozivati u centar gdje se istraživanje provodi, što zahtijeva određena financijska sredstva. Najvažniji nedostatak ovakvih studija

Kohortne i case-control studije relativno su jednostavne za izvođenje, a ako su pažljivo provedene, mogu dati rezultate koji se kvalitetom približavaju randomiziranim kontroliranim studijama.

jest što $s$ vremenom može doći do promjena okolnosti, odnosno ispitanici više ne moraju biti na isti način izloženi faktoru koji se istražuje. Samim time se mijenja i zastupljenost ishoda $u$ takvih ispitanika, što se vrlo često ne može uzeti u obzir pri statističkoj obradi podataka. Na primjer, ako ispitujemo povezanost pušenja i karcinoma pluća, u prospektivnom dizajnu ispitanici možda neće uvijek pušiti isti broj cigareta svakog dana. Možda će neki od pušača na neko vrijeme prestati pušiti pa opet započeti. Ovakvi ispitanici će ostati u skupini u kojoj su ispitivanje i započeli, ali će se njihove razine rizika možebitno vrlo značajno promijeniti. Samim time i ishodi mogu biti skrenuti prema pozitivnom ili negativnom spektru, ovisno o razini izloženosti. Ovakvo skretanje uzrokovano nekim faktorom koji nije uzet u obzir tijekom istraživanja primjer je neočekivanog utjecaja ili engl. confounding ${ }^{7}$.

Sve vrste kohortnih studija pate od još jednog, potencijalno velikog problema. Naime, vrlo često možemo, čitajući rezultate kohortnih studija, naići na zaključak da neki faktor A izaziva ishod B. Drugim riječima, u kohorti ispitanika $s$ rizičnim faktorom A razvija se često ishod B. Zaključak naveden na ovakav način pretpostavlja kauzalni efekt nekog rizičnog faktora na određeni ishod, odnosno navodi na zaključak da će bilo koji pacijent, ako ima takav rizični faktor, bez sumnje razviti i takav ishod. No, vrlo je važno napomenuti 
da kohortne studije ne mogu sa sigurnošću istraživati kauzalnost. One mogu, s druge strane, istraživati asocijacije nekih rizičnih faktora na razvoj bolesti. Drugim riječima, rizični faktor $A$ može se dovesti u vezu s mogućnošću nastanka ishoda $B$, ali se nikako ne može tvrditi da faktor $A$ nužno uzrokuje ishod B. Ovo je česta zamka u koju upadaju mnogi istraživači kod objave rezultata kohortnih studija, a potom i mnogi kliničari koji takve rezultate čitaju u medicinskoj literaturi.

S druge strane, kohortne studije imaju i neke dodirne točke $s$ randomiziranim kontroliranim istraživanjima. Zamislimo da imamo dvije kohorte ispitanika koji boluju od iste bolesti. $U$ jednoj kohorti primijenimo neki eksperimentalni lijek za tu bolest, dok u drugoj kohorti primijenimo placebo. Zamislimo, nadalje, da te kohorte nisu unaprijed određene, nego da se pripadnost kohorti 1 ili 2 određuje u trenutku odluke o primjeni lijeka ili placeba. Također zamislimo da u trenutku odluke o davanju lijeka ili placeba ispitivač nema nikakvog utjecaja na ovu odluku, odnosno da se odluka donosi potpuno neovisno i nasumično. U tom slučaju imamo dvije kohorte ispitanika koji su nasumičnim odabirom dobili lijek ili placebo. Drugim riječima, imamo randomiziranu, placebom kontroliranu studiju. Kako je ranije navedeno, ovakve studije su jedne od najviše cijenjenih u medicini. Ova logika se, naravno, ne odnosi na klasične kohortne studije, iako postoje podaci da su njihovi rezultati iznenađujuće bliski onima iz istovjetnih randomiziranih kontroliranih studija ${ }^{8}$. Međutim, kohortnim studijama se vrlo često, i to iz opravdanih razloga, zamjera na jednom od osnovnih faktora zbog kojih ih se ne može svrstati uz bok suvremenim randomiziranim studijama, a to je confounding ${ }^{9}$.

\section{CASE-CONTROL STUDIJE}

U case-control studijama obično se ispitanici podijele u dvije grupe. Jedna grupa ima određenu bolest koja je od interesa (slučajevi ili engl. cases) dok druga grupa s jednakim karakteristikama nema bolesti (kontrolna skupina ili engl. controls). Case-control studijama pokušavamo identificirati moguće uzroke bolesti tako da istražujemo razlike između dviju skupina u odnosu na izloženost nekom faktoru. Da usporedimo s ranijim primjerom povezanosti pušenja s nastankom karcinoma pluća, u case-control dizajnu imali bismo dvije skupine ispitanika; u prvoj skupini bili bi ispitanici koji svi boluju od karcinoma pluća (slučajevi, engl. cases), a u drugoj skupini bili bi ispitanici koji ne boluju od karcinoma pluća (kontrole, engl. controls). Zatim bismo mogli odrediti koliki je postotak pušača u svakoj od skupina. Ako se taj postotak značajno razlikuje, mogli bismo zaključiti da je pušenje rizični faktor za nastanak karcinoma pluća, odnosno da postoji povezanost pušenja s karcinomom pluća. Ovaj dizajn, case-control dizajn, u stvarnosti je doveo do zaključaka o povezanosti karcinoma pluća s pušenjem, i to na toliko velikom uzorku ispitanika da je zaključak, iako utemeljen na opservacijskoj studiji, toliko snažan i temeljit, da je doveo do potpuno novog pogleda na štetnost pušenja u svijetu te naposljetku i do svjetske kampanje protiv pušenja kojoj smo svjedoci. Dizajnirati randomiziranu kontroliranu studiju koja bi istraživala ovakvo kliničko pitanje bilo bi, naravno, neetično.

Naravno, najbolji podaci iz case-control studija dobili bi se onda kada bi se svi slučajevi neke bolesti u svijetu mogli analizirati. To je nemoguće, stoga se u case-control studijama uzima uzorak ispitanika koji je dostupan istraživačima, ali istovremeno i statistički reprezentativan kako bi istraživanje imalo dostatnu statističku snagu (engl. study power). Ako je snaga istraživanja koja je u direktnoj vezi s veličinom uzorka i frekvencijom pojavnosti određenog ishoda dovoljno velika, onda se rezultati studije mogu primijeniti i na opću populaciju ljudi s istom bolešću ili izloženošću određenom faktoru rizika (slika 2).

Nakon prikupljanja podataka u case-control studijama, obrada podataka se provodi na takav način da se dobivaju vrijednosti vjerojatnosti razvoja bolesti u općoj populaciji u odnosu na to ima li netko ili nema prisutne faktore rizika. Proces provođenja case-control studije i analize podataka prikazan je na slici 3. U ovom procesu analize i interpretacije leži i jedna od glavnih zamki casecontrol studija. Naime, vrlo često povezanost između pojavnosti bolesti i izloženosti faktoru rizika interpretiramo kao uzročno-posljedičnu vezu, odnosno kao stupanj rizika od pojave bolesti u ovisnosti o izloženosti rizičnom faktoru. U stvarnosti nam case-control studija ne može 
Opća populacija

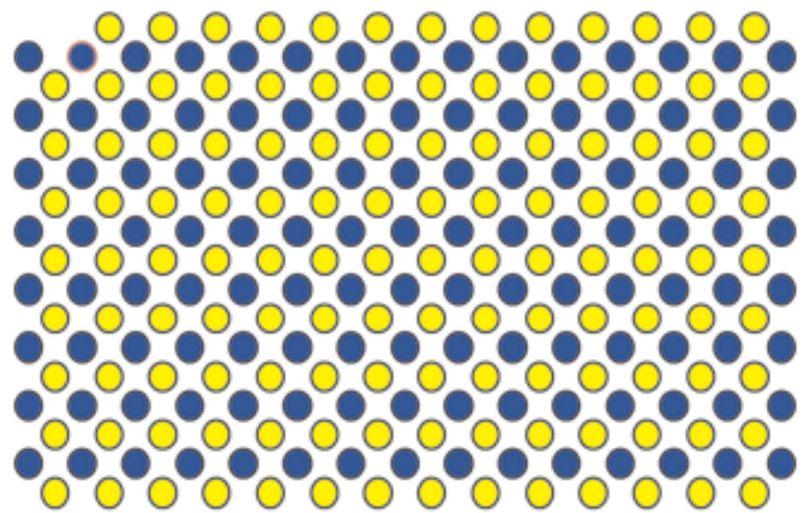

Uzorak
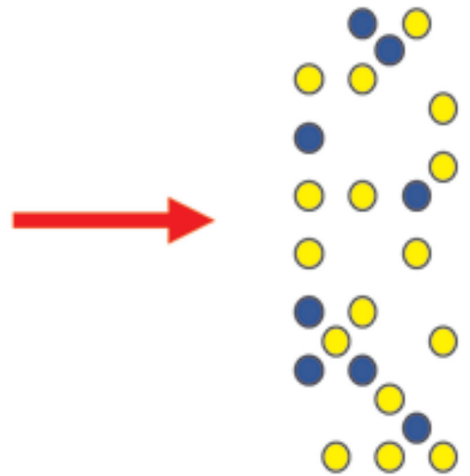

Izloženi

Neizloženi

Slika 2. Usporedba opće populacija i uzorka ispitanika u case-control studijama

omogućiti izračun stupnja rizika, nego rezultate trebamo interpretirati kao vjerojatnost razvoja bolesti u populaciji koja ima prisutan neki faktor rizika. Ovo je vrlo važna, ali često zanemarena razlika. Tako možemo vrlo često učiniti pogrešku ako svojim pacijentima kažemo da imaju, na primjer, 17 \% veći rizik od zaraze gripom ako dolaze u kontakt s djecom. Ono što bismo im trebali reći je da je vjerojatnost zaraze gripom za $17 \%$ veća ako imaju kontakt s djecom od vjerojatnosti koju imaju ako u takav kontakt ne dolaze. Naravno, ako je vjerojatnost veća, samim time veći je i rizik, međutim, rizik od zaraze ovisi o mnogim drugim faktorima, kao o statusu imunosnog sustava, načinu prehrane, vremenu provedenom s djecom i slično. No vjerojatnost se odnosi na apsolutni broj u općoj populaciji koji je, uvjetno rečeno, neovisan o ostalim faktorima.

Vjerojatnost vrlo često ipak ovisi o mnogim drugim faktorima, i u toj se činjenici krije i često nerazumijevanje rezultata case-control studija. Naime, da bi rezultati case-control studije bili vjerodostojni, potrebno je da studija ispunjava neke preduvjete. Prvo, kontrolna skupina mora biti reprezentativna, odnosno, mora biti uzorak koji može adekvatno zamijeniti ciljnu populaciju. U navedenom primjeru, ako istražujemo vjerojatnost zaraze gripom u općoj populaciji, onda u kontrolnoj grupi ne možemo uze-

\begin{tabular}{|c|c|c|c|}
\hline \multirow[t]{2}{*}{ Prva faza: } & & \multicolumn{2}{|c|}{ Odabir ispitanika } \\
\hline & & $\begin{array}{c}\text { Slučajevi } \\
\text { (imaju bolest) }\end{array}$ & $\begin{array}{c}\text { Kontrole } \\
\text { (nemaju bolest) }\end{array}$ \\
\hline \multirow{4}{*}{$\begin{array}{l}\text { Druga faza: } \\
\text { Izloženost }\end{array}$} & Imaju faktor rizika & $\mathrm{a}$ & $b$ \\
\hline & Nemaju faktor rizika & C & $d$ \\
\hline & & $a+c$ & $b+d$ \\
\hline & Proporcije & $\frac{a}{a+c}$ & $\frac{b}{b+d}$ \\
\hline
\end{tabular}


ti uzorak odgajatelja i odgajateljica u vrtićima jer su oni, očigledno, u mnogo češćem kontaktu s djecom nego opća populacija. Ova činjenica sama po sebi ne znači da odgajatelji u vrtićima imaju veći rizik od zaraze gripom. Naime, moguće je da populacija odgajatelja u vrtićima ima, paradoksalno, manji rizik, budući da su u vrlo čestom kontaktu s djecom, te vrlo rano razviju imunitet na virusne infekcije. Dakle, rizik i vjerojatnost ne mogu se poistovjetiti.

Drugi uvjet je da su ispitanici koji imaju određenu bolest reprezentativni u odnosu na cjelokupnu

Kohortne i case-control studije potrebno je interpretirati u kontekstu njihovih nedostataka, a to su prvenstveno rizici od sustavne pogreške te utjecaj nepredviđenih faktora na rezultate (engl. bias; confounding).

populaciju koja ima tu istu bolest. Drugim riječima, svi stadiji, različite prezentacije ili stupnjevi težine bolesti moraju biti zastupljeni u skupini ispitanika da bi ta skupina bila reprezentativna, a samim time da bi se onda i rezultati studije mogli primijeniti na cjelokupnu populaciju pacijenata $s$ tom istom bolesti.

Prednosti case-control studija su višestruke. Ove studije su, za razliku od randomiziranih kontroliranih studija, mnogo jednostavnije za provođenje. Zahtijevaju mnogo manji uzorak, budući da se odabir vrši obično prema kriterijima prisutnosti ili odsutnosti bolesti, te je obično ograničavajući faktor samo prevalencija ili incidencija pojedine bolesti u populaciji. Case-control studije su vjerojatno najbolji izbor u slučajevima kada želimo istražiti karakteristike nekih vrlo rijetkih bolesti. To je tako upravo zbog prirode case-control studija, u kojima su nam ispitanici s bolešću jedna od interesnih skupina. Samim time, jednostavnije je pronaći ciljano ispitanike s određenom rijetkom bolešću ako ih aktivno pokušavamo naći i uključiti u istraživanje, nego ako se oslanjamo na kohorte slučajnih pacijenata.

Kako je ranije navedeno, postoje i određena ograničenja, Prvo je u tome da su case-control studije, kao i sve opservacijske studije, vrlo podložne confoundingu. Skretanje rezultata (bias) je isto tako vrlo čest problem zbog odsustva randomizacije, tako da se skupine pacijenata mogu značajno razlikovati zbog slučajnih nenamjernih pogrešaka pri odabiru pacijenata za istraživanje. Isto tako, i kontrolna skupina može biti nenamjerno pogrešno odabrana, tako da rezultati nisu vjerodostojni, čak i ako je skupina ispitanika koji imaju bolest vrlo pažljivo odabrana.

\section{ZAKLJUČAK}

U svojem svakodnevnom radu liječnici se vrlo često susreću s izborom među nekoliko različitih intervencija ili lijekova. Također, pacijentima ponekad trebaju dati savjet o ponašanju kako bi vjerojatnost da obole sveli na najmanju moguću mjeru. Vrlo često ovakve podatke dobivamo iz opservacijskih studija. Ako imamo na umu potencijalne zamke ovakvih studija, no isto tako i njihove prednosti, onda nam shvaćanje rezultata neće predstavljati problem. Svaka opservacijska studija, pa tako i kohortne i case-control studije, imaju neke svoje prednosti pred svim ostalim vrstama istraživanja u kliničkoj medicini. Ako se njihovi istovremeni nedostatci svedu na minimum, te ako se određeni dizajn studije prilagodi kliničkom pitanju, onda nam mogu dati vrlo vrijedne kliničke informacije.

Izjava o sukobu interesa: autori izjavljuju da ne postoji sukob interesa.

\section{LITERATURA}

1. ocw.tufts.edu [internet]. Hyde J. Lecture 2: Observational Studies. Tufts Open Course Ware 2004: Tufts University [cited 2017 May 20]. Available from: http://ocw. tufts.edu/data/1/194039.pdf.

2. stats.org [internet]. Stats FAQ. George Mason University Statistical Assessment Service. StatsORG 2011[cited 2017 May 20] Available from: http://stats.org/in_depth/faq/controlled_vs_observational.htm.

3. medicalnewstoday.com[internet]. MacGill M. What is a cohort study in medical research? [cited 2017 May 20]. Available from: http://www.medicalnewstoday.com/articles/281703.php.

4. Rosenbaum PR. Design of observational studies. J Rosenbaum (editor). New York: Springer-Verlag, 2010.

5. Song JW, Chung KC. Observational Studies: Cohort and Case-Control Studies. PlastReconstrSurg 2010;126:2234-42.

6. Mann CJ. Observational research methods. Research design II: cohort, cross sectional, and case-control studies. Emerg MedJ 2003;20:54-60.

7. Jepsen P, Johnsen SP, Gillman MW, Sorensen HT. Interpretation of observational studies. Heart 2004;90:956-60.

8. Concato J, Shah N, Horwitz RI. Randomized, controlled trials, obsevational studies and the hierarchy of research designs. N Engl J Med 2000;342:1887-92.

9. Hartz A, Bentler S, Charton M, Lanska D, Butani Y, Soomro GM et al. Assessing observational studies of medical treatments. Emerg Themes Epidemiol 2005;2:8. 